\title{
An Empirical Assessment of Transformational Leadership in Institutions of Higher Learning
}

\author{
Umar Mufeed \\ Research Scholar \\ Department of Management Studies, University of Kashmir, Jammu and Kashmir, India \\ E-Mail: umar.mufeed08@gmail.com
}

\begin{abstract}
The purpose of this paper is to examine the perception of employees towards transformational leadership prevailing in sample select universities. The respondents in this study comprise of 169 teaching and 97 non- teaching staff selected from four universities of North India. Multi factor Leadership questionnaire (MLQ- 5x) developed by bass and Avolio (1995) was employed to gather the responses from the respondents. The data collected were analyzed using descriptive and inferential statistics. The results of the study revealed that there prevails a favorable perception among employees regarding transformational leadership practices. Teaching staff have showed higher satisfaction towards existing transformational leadership practices as compared to non-teaching staff. The study suggests that academicians and policy makers must promote transformational leadership style in order to improve employee delivery and enhance institutional performance in sample select universities.
\end{abstract}

Keywords: Leadership, Transformational Leadership, Academic and Nonacademic staff, Universities, India

\section{INTRODUCTION}

The subject of leadership has been discussed threadbare in previous literatures and over the years has gained immense relevance among researchers, academicians and policy makers in this knowledge driven economy. Leadership continues to be considered as widely debated issue at global platform (Kuchler, 2008). Leader's role in maneuvering the resources in terms of physical, human and capital have widely been accepted for improving the competence and efficiency of organizations irrespective of their nature, size and control. Yukl and Van Fleet (1992) pointed out that significance of leadership can help in achieving desired results each at individual, group and organizational level.

Previous literature on leadership revealed that the success factor of organizations depends upon the extent to which their leaders have the ability and vision to transform their institutions (Northouse, 2015; March \& Weil, 2005 and Lok and Crawford 2004). Bass and Avolio (1990) opined that leadership is one of the most essential building blocks for institutional building. Due to the complex nature of environment the need for developing leadership competencies becomes all more important especially in educational institutions (Mead, Morgan \& Heath, 1999; Knight \& Trowler, 2001; and Cohen, 2004). Ramsden (1994) in his research work pointed out that sound and effective academic leadership will lead to create strategic advantage over global players. Somalingam \& Shanthakumari (2013) shared that role of academic leaders will increase manifold due to changes in increasing aspirations of stakeholders, advancement in technology, new trends in teaching and research, developing world class universities, environmental complexity and huge demand for skilled and knowledgeable workforce.

Various leadership styles have been developed over the years by many researchers each having its relevance and applicability. Transformational leadership style has been studied in much detail in various organizational settings. Hall et al (2008) opined that transformational leadership helps people to change their behavior and transform them to perform better. Transformational leadership articulates the vision of an institution and allows its followers to strive in attainting its objectives. Bass and Riggio (2006) transformational leadership promotes inspiration among its followers and helps them to be committed towards their institutional vision. Transformational leaders help in articulating a vision through which they emphasize the need of followers to align their values and to put efforts in achieving the laid down goals, Hoffman et al., (2011). Transformational leadership behavior contributes significantly towards attaining organizational goals and in determining its success (Amin and Hassan, 2010; Laohavichien, et.al. 2009 and Burns, 2004). According to Li and Hung (2009) transformational leadership helps in developing the relationships between leader and his followers for achieving desired outcomes.Transformational leadership consists of five contructs which are: idealised attribute, idealised behaviour, inspirational motivation, intellectual stimulation and individualized consideration (Antonakis, Avolio, and Sivasubramaniam, 2003; Avolio and Bass, 2004 and Johnson, 2009).

In educational institutions, transformational leadership style is considered as very relevant as it helps in inspiring the followers to share common goals and communicate the vision among its members for attaining organizational objectives. Middlehurst, et. al. (2009) advocated for transformational leadership in higher education whereby 
leader inspires followers through a shared vision for the future. The success and failure of institutions are rooted in how well they can attract and retain dynamic, talented and futuristic leaders who have the potential and vision in taking universities to higher levels and in attaining global competitiveness.

Past studies have focused on transformational leadership practices in western settings (Long, Yusof, Kuwong and Heng, 2014; Shusha, 2013; Thamrin, 2012 and Bushra, et al 2011) but not much has been explored in Indian context. Even if some work has been examined in various organizational settings in India (Bandarker and Rai, 2015; and Kour, 2012) but service sector in general and educational sector in particular have not been studied in detail. Therefore, keeping this in view, the present paper is an attempt to examine the transformational leadership practices in universities in India.

\section{RESEARCH METHODOLOGY}

\section{A. Research Objectives}

The following objectives have been laid down for the present study:

1. to study the existing perception of employees perception towards transformational leadership practices prevailing in sample select universities,

2. to compare the perception of teaching and non-teaching staff regarding transformational leadership practices,

3. to examine the perception of employees on the basis of age and gender and

4. To draw conclusions and suggest measures based on findings for improving the transformational leadership practices in sample select universities.

\section{B. Hypotheses}

Keeping in view the above objectives, the following hypothesis has been formulated for the present study:

H1. The perception of teaching and non- teaching staff differs from each other.

H2. The perception of male and female staff towards transformational leadership does not differ from one another.

\section{Research Instrument}

To collect information from respondents about transformational leadership prevailing in sample select institutions, a research instrument Multi Factor questionnaire (MLQ-5x) comprising of 20 items developed by Bass and Avolio (1995) was used. It measures transformational leadership on five elements namely idealized attribute, idealized behavior, inspirational motivation, intellectual stimulation and individual consideration. Each element consists of 4 items each. Items are measured using five point likert type scale ranging from "strongly disagree" to "strongly agree".

\section{Reliability and Validity Test}

It is very important for the empirical studies to test the reliability of the variables as it depicts to what extent variables can produce consistent results if computed or calculated repeatedly. The most widely used method to check the reliability is Cronbach's Alpha Test. In the present study we, therefore used Cronbach's Alpha Test in order to measure reliability and is clearly depicted as under:

TABLE I RELIABILITY OF CONSTRUCTS

\begin{tabular}{|c|l|c|c|}
\hline S. No. & \multicolumn{1}{|c|}{ Variables } & No. of Items & $\begin{array}{c}\text { Cronbach's } \\
\text { Alpha }\end{array}$ \\
\hline 1 & Idealized attribute & 4 & 0.79 \\
\hline 2 & Idealized behavior & 4 & 0.82 \\
\hline 3 & Inspirational motivation & 4 & 0.74 \\
\hline 4 & Intellectual simulation & 4 & 0.72 \\
\hline 5 & Individual consideration & 4 & 0.84 \\
\hline
\end{tabular}

A pre-test on 50 employees was done to check the validity of the instrument and it was found quite valid as no issues were reported while responding to the framed questions and thus used for final analysis.

\section{E. Data Collection}

The study was performed on four universities of North India. The study targeted 360 employees out of which only 277 questionnaires were received back. Out of the 277 questionnaires returned, eleven responses were found either incomplete or not fit for analysis. Therefore 266 questionnaires were used for final analysis representing usable response rate of $73.88 \%$. The questionnaire also gathered information on demographic variables such as gender and age. Male staff comprised of 154 employees (57.89\%). Employees having more than fifty years of age consisted of 104 (39.09\%) while those having age between 40-50 years represented 87 employees $(32.70 \%)$ and employees having age between 30-40 years represented 75 (28.20\%).

\section{F. Sample Study Organizations}

The present study was restricted to the Higher Educational Institutions. It is to be mentioned that institutions were confined within North India. The present study targeted 4 universities which were comprised of 2 State universities and 2 central universities.

The sample institutions included University of Kashmir (Kashmir), Punjab University (Chandigarh), Delhi University (Delhi) and Aligarh Muslim University (Aligarh). The selection of universities was based on purposive sampling while respondents were targeted on the basis of proportionate random sampling. 


\section{FINDINGS AND DISCUSSION}

TABLE II PERCEPTION OF EMPLOYEES TOWARDS TRANSFORMATIONAL LEADERSHIP PRACTICES

\begin{tabular}{|l|c|c|}
\hline \multicolumn{1}{|c|}{ Dimension } & $\begin{array}{c}\text { Mean Score } \\
(\mathbf{N = 2 6 6 )}\end{array}$ & $\begin{array}{c}\text { Std. } \\
\text { Deviation }\end{array}$ \\
\hline Idealized attribute & 3.34 & .72 \\
\hline Idealized behavior & 3.39 & .68 \\
\hline Inspirational motivation & 3.25 & .80 \\
\hline Intellectual simulation & 3.29 & .77 \\
\hline Individual consideration & 3.23 & .85 \\
\hline $\begin{array}{l}\text { Transformational } \\
\text { Leadership }\end{array}$ & 3.30 & .79 \\
\hline
\end{tabular}

Source: Data compiled by the author for the present study
The perception of employees towards transformational leadership practices depicts that employees are satisfied as the same is revealed with overall mean score of 3.30 (Table II). Among the elements of transformational leadership employees have shown higher satisfaction towards idealized behavior with mean score of (3.39) followed by idealized attribute, intellectual stimulation, inspirational motivation with mean scores of (3.34), (3.29) and (3.25) respectively. The employees showed least perception (3.23) with the element individual consideration. The overall mean scores depicts a favorable and positive perception of academic and nonacademic staff with respect to transformational leadership and its five elements.

TABLE III COMPARISON OF TEACHING AND NON-TEACHING STAFF PERCEPTION TOWARDS TRANSFORMATIONAL LEADERSHIP

\begin{tabular}{|c|c|c|c|}
\hline \multirow{2}{*}{ Constructs } & \multicolumn{2}{|c|}{ Mean score } & \multirow{2}{*}{ Z Value* } \\
\hline & Teaching Staff $(\mathbf{N = 1 6 9 )}$ & Non- Teaching Staff (N= 97) & \\
\hline Idealized attribute & 3.42 & 3.26 & .026 \\
\hline Idealized behaviour & 3.48 & 3.30 & .018 \\
\hline Inspirational motivation & 3.33 & 3.17 & .031 \\
\hline Intellectual simulation & 3.37 & 3.21 & .029 \\
\hline Individual consideration & 3.30 & 3.16 & .042 \\
\hline Transformational Leadership & 3.38 & 3.22 & $.036 *$ \\
\hline
\end{tabular}

A comparative analysis was used to measure the perceptual differences between teaching and non-teaching staff of sample select universities towards transformational leadership practices (Table III). The results of the study reveal that academic staff of sample select universities showed higher satisfaction towards transformational leadership and its elements with overall mean score of (3.38) as compared to non-teaching staff (3.22). A z test was employed to ascertain whether the difference in the mean score of the two respondent groups is statistically significant or not. The results depicted that the difference is statistically significant $(\mathrm{z}$ value $=0.036 ; \mathrm{p}<.05$ ), indicating that the perception of the academic and non-academic staff towards transformational leadership practices prevailing in their universities differs from each other. Therefore, our hypotheses I is empirically supported and hence accepted.

TABLE IV PERCEPTION OF EMPLOYEES TOWARDS TRANSFORMATIONAL LEADERSHIP ACROSS AGE

\begin{tabular}{|c|c|c|c|c|c|c|}
\hline Factor & Dependent Variable & Group & $(\mathrm{N})$ & Mean Score & ANOVA & Sig* \\
\hline \multirow{3}{*}{ AGE } & \multirow{3}{*}{ Transformational Leadership } & 30 - 40 years & 104 & 3.23 & \multirow{3}{*}{3.592} & \multirow{3}{*}{$.048^{*}$} \\
\hline & & 40- 50 years & 87 & 3.31 & & \\
\hline & & $>50$ years & 75 & 3.36 & & \\
\hline
\end{tabular}

The table IV examines the difference in the perception of academic and non-academic staff regarding transformational leadership on the basis of variable age. It is revealed from the above table 3 that employees who are above 50 years age are having highest perception towards transformational leadership with mean score of (3.36) while as employees in between 30-40 age group showed least satisfaction towards transformational leadership with mean score of (3.23).

The perceptual differences of respondent employees regarding transformational leadership is statistically significant when the differences were examined on the basis of age factor (ANNOVA=3.592; $\mathrm{p}<.05$ ). 
TABLE V PERCEPTION OF EMPLOYEES TOWARDS TRANSFORMATIONAL LEADERSHIP ACROSS GENDER

\begin{tabular}{|c|c|c|c|c|}
\hline Construct & Gender & $\mathbf{( N )}$ & Mean Score & Std. Deviation \\
\hline Transformational & Male & 154 & 3.26 & 0.78 \\
\cline { 2 - 5 } Leadership & Female & 112 & 3.34 & 0.73 \\
\hline \multicolumn{3}{|c|}{ Source: Data compiled by the author for the present study }
\end{tabular}

As is evident from the table $\mathrm{V}$. the female staff showed higher satisfaction with mean score of (3.34) towards transformational leadership as compared to male staff with mean score of (3.26) in sample select universities. To know whether the difference in respondent group 'gender' is statistically significant or not, an independent samples test was employed. The results showed that the difference in the perception of female and male staff towards transformational leadership is statistically significant as the p value is less than .05 (table VI). Therefore hypotheses II is empirically supported and hence accepted.

TABLE VI INDEPENDENT SAMPLES TEST (GENDER)

\begin{tabular}{|c|c|c|c|c|c|c|}
\hline \multirow{2}{*}{ Construct } & \multicolumn{2}{|c|}{ Levene's Test for Equality of Variances } & \multicolumn{4}{c|}{ t- test for Equality of Means } \\
\cline { 2 - 7 } & F & Sig. & T & Df & Sig. (2- tailed) & Mean Difference \\
\hline Transformational Leadership & .533 & .578 & -1.220 & 266 & .041 & -.08971 \\
\hline
\end{tabular}

\section{CONCLUSIONS}

The purpose of this study was to examine the existing perception of academic staff and non-academic staff towards transformational leadership prevailing in sample select universities. The results of the study revealed that both academic and non-academic staff showed favorable perception towards transformational leadership practices. Further it was indicated from the findings that academic staff showed higher satisfaction as compared to nonteaching staff. Similarly, female staff of sample select universities showed higher perception as compared to male staff, also the statistically significant difference between them depicted that gender has an effect on the perception of respondents towards transformational leadership. On the basis of findings, the statistically significant difference suggests that age has an effect on the perception of respondent employees regarding transformational leadership.

The present study is faced with some limitations. Firstly, the study targeted only five universities in India and that too with less sample size. As such the findings of the study cannot be generalized. Therefore future research can include other universities with wider geographical representation. Secondly, only public universities were taken in the present study, therefore future research can include private universities as well in order to capture and generalize the results. Thirdly, only two demographic variables such as age and gender were studied therefore future research can consider other factors namely experience, designation and Qualification so that transformational leadership can be studied through various spectrums.

\section{REFERENCES}

[1] B. M. Bass and B. J. Avolio, "Developing transformational leadership: 1992 and beyond”, Journal of European Industrial Training, Vol. 14, pp. 21-27, 1990.

[2] G. Yukl and D.D. Van Fleet, "Theory and research on leadership in organizations", In M.D, 1992.

[3] B. M. Bass and B. J. Avolio, "Multifactor Leadership Questionnaire", Mind Garden, .Palo Alto CA, 1995.

[4] P. Ramsden, "Managing the Effective University", Higher Education Research and Development, Vol. 17, No. 3, pp. 347-370, 1998.

[5] P. Mead, M. Morgan and Heath, C, "Equipping leaders to capitalise on the outcomes of quality assessment in higher education", Assessment and Evaluation in Higher Education, Vol. 24, No. 2, pp.147-156, 1999.

[6] P. Knight and P.R.Trowler, "Departmental leadership in higher education", Buckingham: Society for Research into Higher Education and Open University Press, 2001.

[7] W. H. Gmelch, "The call for department leaders". New York: Paper presented at the Annual Meeting of the American Association of Colleges for Teacher Education, 20002.

[8] J. Antonakis, B. J. Avolio and N. Sivasubramaniam, "Context and Leadership: An Examination of the Nine-Factor Full-Range Leadership Theory Using the Multifactor Leadership Questionnaire”, The Leadership Quarterly, Vol. 14, pp. 261-295, 2003

[9] B. J. Avolio, and B. M. Bass, "Multifactor Leadership Questionnaire: Manual and Sample Set", 3rd Ed., Retrieved from www.mindgarden.Com, 2004.

[10] B. Burnes, "Managing Change", 4th ed., London: Prentice Hall, 2004.

[11] P. Cohen, "The crisis of the university. Campus Review, April 21-27, 9-12, 2004

[12] P. Lok and J. Crawford, "The effect of organizational culture and leadership style on job satisfaction and organizational commitment: A cross-national comparison", Journal of Management Development, Vol. 23, No. 4, pp. 321-338, 2004.

[13] J. G. March and T. Weil, "On leaderhip”, Malden, MA: Blackwell, 2005.

[14] B. M Bass and R. E. Riggio, "Transformational leadership”, 2nd ed., Mahwah NJ: Lawrence Erlbaum Associates, 2006.

[15] W. G. Conningham and P. A. Corderio, "Educational leadership: a problem-based approach”, Boston, MA:Pearson Education Inc., 2006.

[16] A. S. Gill, A. B. Flaschner and M. Shacha, "Mitigating stress and burnout by implementing transformational-leadership", International Journal of Contemporary Hospitality Management, Vol. 18, No.6, pp. 469-481, 2006. 
[17] M. J Albion and R. E. Gagliardi, "A study of transformational leadership, organizational change and job satisfaction”. Retrieved from http://eprints.usq.edu.au/3098/1/Albion_Gagliardi.pdf, 2007.

[18] P. J. Jeroen de Jong and Deanne N. Den Hartog, "How leaders influence employees' innovative behaviour", European Journal of Innovation Management, Vol. 10, No. 1, pp. 41-64, https://doi.org/10.1108/14601060710720546, 2007.

[19] P. G. Northouse, "Leadership: Theory and practice", (4th ed.). Thousand Oaks, CA: Sage Publications, Inc, 2007.

[20] J. Hall, S. Johnson, A. Wysocki and K. Kepner, "Transformational Leadership: The transformation of Managers and Associates. University of Florida”, Florida, 2008.

[21] W. J. Kuchler, "Perceived leadership behavior and subordinates' job satisfaction in Midwestern NCAA division 3 athletic departments", The Sport Journal, Vol. 11, No. 2, 2008.

[22] R. M. Johnson, "Transformational and Transactional Leadership and Performance”, Journal of the Academy of Marketing Science, Vol. 29, No. 23-30, 2009.

[23] T. Laohavichien, L. D Fredendall, and R. S. Cantrell, "The effects of transformational and transactional leadership on quality improvement”, The Quality Management Journal, Vol. 16, No. 2, pp. 7-24, 2009.

[24] $\mathrm{C}-\mathrm{K} \mathrm{Li}$, and $\mathrm{C}-\mathrm{H}$. Hung, "The influence of transformational leadership on workplace relationships and job performance”, Social Behavior and Personality, Vol. 37, pp. 1129-1142, 2009. doi:10.2224/sbp.2009.37.8.1129.

[25] R. Middlehurst, H. Goreham and S Woodfield, "Why research leadership in higher education? Exploring contributions from the UK's leadership foundation for higher education”. Leadership, Vol. 5, No. 3, pp. 311- 329, 2009.

[26] Amin and Abu Hassan, "Towards assessing the leadership style and quality of transformational leadership, the case of construction firms of Iran”, Journal of Technology Management, Vol. 5, No.3, pp. 245258, 2010.
[27] W. P. Cordeiro, "A business school's unique hiring process", Business Education Innovation Journal, Vol. 2, No. 1, pp. 56-60. Retrieved from http://www.beijournal.com/, 2010.

[28] F. Bushra, A. Usman and A. Naveed, "Effect of Transformational Leadership on Employees' Job Satisfaction and Organizational Commitment in Banking Sector of Lahore (Pakistan)", International Journal of Business and Social Science, Vol. 2, No. 18, October 2011.

[29] B. J. Hoffman, B. H.Bynum, R. F.Piccolo and A. W. Sutton, "Personorganization value congruence: How transformational leaders influence work group effectiveness", Academy of Management Journal, Vol. 54, No. 4, pp. 779-796, 2011.

[30] R. Kaur, "Transformational and transactional leadership behavior in selected public and private sector banks in Chandigarh", International Journal of Engineering and Management Sciences, IJEMS, Vol. 3, No. 2, pp. 126-133, 2012.

[31] H.M. Thamrin, "The Influence of Transformational Leadership and Organizational Commitment on Job Satisfaction and Employee Performance”, International Journal of Innovation, Management and Technology, Vol. 3, No. 5, October 2012.

[32] Somalingam and R. Shanthakumari, "The Changing Role of Academic Leadership”, Educationia Confab, Vol. 2, No. 1, 2013.

[33] A. Shusha, "The Mediating Role of Leader-Member Exchange in the Relationship between Transformational Leadership and Job performance”, European Journal of Business and Management, Vol.5, No.8, 2013.

[34] C.S Long, M. Yusof, T.O. Kowang, and L.H, Heng, "The Impact of Transformational Leadership Style on Job Satisfaction”, World Applied Sciences Journal, Vol. 29, No.1, pp. 117-124, 2014.

[35] A. Bhandarker and S. Rai, "Positive transformational leadership: case study of an Indian public sector bank", Asia-Pacific Journal of Business Administration, Vol. 7, No.1, pp.34-55, 2015. [Online] Available: https://doi.org/10.1108/APJBA-03-2014-0044

[36] P. G. Northouse, "Leadership: Theory and practice", 7th ed. Thousand Oaks, CA: Sage, 2015. 